The Polish Journal of the Arts and Culture. New Series 9

(1/2019): 117-133 [ARTICLE]

DOI: $10.4467 / 24506249$ PJ.19.005.11137

\title{
Between politics and religion. The reasons for the meeting of the 6th Panchen Lama Palden Yeshe and the Qianlong Emperor in 1780 in China
}

\section{Maksymilian WocH}

\begin{abstract}
The purpose of the text is to present and discuss the possible reasons which induced the Qianlong Emperor to invite the 6th Panchen Lama Palden Yeshe to visit China, in light of the possible factors which influenced the acceptance by the latter of the invitation to visit the Manchu court. The article constitutes an analysis and a comparison of the concepts presented in scholarly articles devoted to Tibetan-Manchu relations in the middle of the 18 th century. The context for the subject under discussion is furnished by the representation of the question of the mutual relations of politics and religion.
\end{abstract}

Keywords: Panchen Lama, Palden Yeshe, Qianlong Emperor, yon mchod

Maksymilian WocH a religious studies expert and anthropologist, a PhD student of the Department of Philosophy of the Jagiellonian University, a researcher of Tibetan culture and of the philosophy of Buddhism. He is currently developing his $\mathrm{PhD}$ thesis devoted to the institution of tulku in Tibetan Buddhism.

E-MAIL: maksymilianwoch@gmail.com 


\section{Introduction}

The question of the relation between the court of Peking and the administration of Tashi Lhunpo (Tib. bkra shis lhun po) during the 6th Panchen Lama's lifetime ( $p a N$ chen bla ma), Palden Yeshe (dpal ldan ye shes), affects above all his voyage to China, which was undertaken in 1779 upon the invitation of the Qianlong Emperor. In the period of the rule of the Qing dynasty, this was the only case when a Tashi-Lama visited the Manchu court. The sojourn, which, as it seems, was the source of great hopes on the part of both parties, the Manchu and the Tibetan parties, ended with the unexpected death of the Panchen Lama in Peking, which was most likely caused by the contraction of smallpox. The concerns associated with the epidemic which ravaged China at that time (which, after all, constituted a convenient excuse before the undertaking of a journey), expressed both by the previous Panchen Lama, Lobsang Yeshe (blo bzang ye shes), and the subsequent one, Palden Yeshe, were thus confirmed. The 6th Panchen Lama, immersed in meditation ${ }^{1}$, died on 26 November 1780 , at the age of 42 .

What were the reasons for the meeting of Emperor Qianlong and 6th Panchen Lama in China? Explanation in this regard is furnished above all by the knowledge of the political and cultural-religious context of this event. At

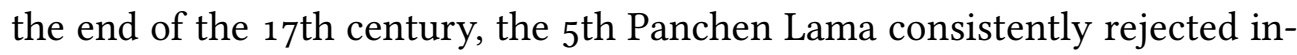
vitations from the Kangxi Emperor, which was influenced by the decisions of the desi Sanggye Gyatso (sde srid sangs rgyas rgya mtsho). ${ }^{2}$ However, almost 80 years later, another Panchen Lama was able to make a decision about the excursion in a more or less independent manner. After the death of the regent 7 th Demo Tulku (de mo sprul sku), Jampal Delek Gyatso ( 'jam dpal bde legs rgya mtsho) in 1777, the 6th Panchen Lama practically became the most important figure on the political scene of Tibet, even if we also take into account the adolescent Jampal Gyatso ('jam dpal rgya mtsho), i.e. the 8th Dalai Lama (ta lai bla ma), who, after all, did not manifest particular political aptitude. It is worthwhile to remember that the 6th Panchen Lama, similarly as his predecessor, initially rejected the imperial invitation a number of times, citing the concern about contracting smallpox, even though, according to other sources, he had been harbouring the intention of embarking upon this journey for a long time. ${ }^{3}$ It was only the invitation to participate

1 S. van Schaik, Tibet, p. 155.

${ }^{2}$ H. Ya, Biographies of Tibetan Spiritual Leaders, p. 72.

3 W. Xiangyun, The Qing Court's Tibet Connection: Lcang skya Rol pa'i rdo rje and the Qianlong 
in the celebration of the seventieth anniversary of Qianlong's birth, organised in the summer imperial resort in Jehol, that encouraged the Tashi-Lama to undertake preparation for the journey. Therefore, if one inquires about the factors which brought about this meeting, one should take into account the motivation which induced the Emperor to issue an invitation, and the reasons which underpinned the Panchen Lama's decision to undertake this journey.

\section{The metaphysical dimension of the political meeting}

In the socio-political dimension, the meeting of the emperor and the Panchen Lama was a spectacular meeting of two monarchs, a secular one and a religious one, both of whom wielded power in the dominion which represented its respective prerogatives. However, such an image represents only partially the nature of the things which transpired in Jehol on $20^{4}$ or $21^{5}$ or $22^{6} \mathrm{Au}-$ gust 1780 , for the complete image consists also of the metaphysical plane of the meeting of Qianlong - a personification of the bodhisattva of wisdom, Mañjuśrī ('jam dpal dbyang) with the Panchen Lama - who was considered an emanation of Buddha Amitabha ('od dpag med). Both officials, who thus represented somehow a higher order, legitimised the "earthly" hierarchy of power which they represented. It is in this respect, that one of the reasons which brought about the event in question was associated with the desire to solidify the position of the emperor as both a secular and a religious ruler. This occurred, after all, with the consent of the Tibetan people, as during one of the conversations with the Emperor held in Jehol, Panchen referred to the former as the "God of Heavens" and a "Mañjuśri”." ${ }^{7}$ One should add that the emperors of the Qing dynasty considered themselves incarnations of bodhisattva Mañjuśri $\bar{i}^{8}$, although due to political reasons, this fact was not

\footnotetext{
Emperor, p. 152.
}

4 N. D. Ragnubs (trans.), The Third Panchen Lama's visit to Chengde, p. 188.

5 M. M. Shu-yi Loo., The Biography of the III Panchen Lama Blo-bzang-dpal-Ldan-yes-she-dpalbzang-po, Examined in the Light of Sino-Tibetan Relations during the late Eighteen Century, p. 120.

6 W. Xiangyun, op. cit., p. 155.

7 N. D. Ragnubs, op. cit., p. 194.

8 D. M. Farquhar, Emperor as Bodhisattva in The Governance of The Ch'ing Empire, p. 33. 
publicised in China itself. Successive rulers skillfully played out their own image of the emanation of the mind of the Buddha, at the same time criticising the Buddhist clergymen, in order to seek the support of part of the elites of the Chinese subjects. This remark should be supplemented by mentioning the existence of an internal opposition among the Chinese Buddhists, who represented a negative attitude toward the favouring of Tibetan Buddhism. ${ }^{9}$ Due to this fact, it is difficult to evaluate in an unambiguous manner the extent of Qianlong's engagement in the practice and propagation of Buddhist religion. These doubts are also not modified by the fact that the Emperor was represented in Buddhist iconography as a personification of Mañjuśrī ${ }^{10}$ It is a fact that Changkya Rölpé Dorjé (lcang skya rol pa'i rdo rje), a Tibetan monk, one of the closest collaborators and at the same time, a spiritual mentor, was a reincarnation in one of the lines of the gelug ${ }^{11}$ (dge lugs). This was, after all, a man of extremely great influence at the Manchu court, who was educated a parvulo (...) to perform the function of an intermediary between the centre of the power of the Manchu and the Buddhists of Tibet and Mongolia. ${ }^{12}$ Rolpa Dorje is an important figure in the context of the events under discussion, not only due to the fact that he was a trusted man of the Emperor, but also due to the fact that he somehow linked Qianlong and Palden Yeshe, for when the Panchen Lama reached Jehol in the summer of 1780 , Rolpa Dorje was one of the imperial officials who were sent to welcome the guest. This was when the long-expected meeting of both lamas happened. They knew each other earlier, owing to the participation in the quest for and the recognition of the 8th Dalai Lama . ${ }^{13}$ It was at that time that the desire expressed by the Panchen Lama in a letter to Rolpe Dorje, on the possibility of a meeting and the joint continuation of Buddhist studies, came to fruition. When we summarise this aspect of Panchen Lama's visit, we should recognise that it represented a religious tenor of its own, which was advantageous, above all, in terms of the image of Tibetan Buddhism among its adherents in China, Mongolia and Tibet, for both the Panchen Lama, who was a high-ranking Buddhist official, and the Qianlong Emperor, who promoted the vision of himself as a bodhisattva, which solidified the political and social order whose foundation was religion.

9 E. Ludwig, The Visit of the Teshoo Lama to Peking, p. 16.

${ }^{10}$ E. Benard, The Qianlong Emperor and Tibetan Buddhism.

${ }^{11}$ S. M. Grupper, Manchu Patronage and Tibetan Buddhism During the First Half of the Ch'ing Dynasty, p. 47.

${ }^{12}$ M. T. Kapstein, Tybetańczycy, p. 160.

${ }^{13}$ S. van Schaik, Tibet, p. 152. 
This religion was Tibetan Buddhism, in the version represented by the gelug school, which was also followed by the Panchen Lamas. It is also due to this fact that both officials benefitted from the meeting.

\section{The reasons which prompted Qianlong to issue an invitation}

The motivation which prompted Emperor Qianlong (and) the 6th Panchen Lama to engage in a meeting could have been different in reference to both of the parties involved. As far as the political plane is concerned, for Qianlong, a spectacular celebration of his birthday in Jehol was an opportunity to confirm the unshakable position of the imperial throne in China, and the authority over the anteriorly subordinated parts of the empire. In a similar manner, from the point of view of the 6th Panchen Lama, the visit could have represented propaganda action. Even though the Mongol people, after the fall of the Dzungar Khanate, ceased to pose a threat to the Qing ${ }^{14}$ dynasty, nevertheless, Qianlong attempted to solidify the central authority by legitimising it on the symbolic-religious plane. In order to service this ambition, it was necessary for him to gain the support of the gelug hierarchs, and the appeal of the institution of the Panchen Lama, which was unquestioningly revered by the Mongol people. Such a point of view was pointedly expressed by one of the Jesuits who were at Qianlong's court, Father Amiot, who made his name by translating a letter of the Emperor to the 8th Dalai Lama, in which he informed him of the fact of Panchen's death in Peking. According to him, the Tashi-Lama's visit in Jehol constituted the realisation of an imperial plan to subjugate the Mongol people, whom the Christian missionary referred to as Tartars, even more thoroughly. ${ }^{15}$ Both the Tibetan and the Mongol people intended to perceive the secular authority as the one which has religious justification. In the Buddhist image of the world and in the Tibetan version, there was an inextricable link between both orders, the secular and the religious one, which manifested itself in the concept of chos srid zung 'brelthe co-existence of both traditions. The khans and the minor Mongol rulers, who professed Tibetan Buddhism, continuously sought the support for their own political aspirations, making reference to their religious justification,

\footnotetext{
${ }^{14}$ Baabar, Dzieje Mongolii, p. 121.

${ }^{15}$ W. Xiangyun, op. cit., p. 159.
} 
and also appearing as the patrons and the guardians of religion. The Qing dynasty rulers, who were aware of such a situation, skillfully played out the aspects of this theory which could serve the realisation of their own political goals. ${ }^{16}$ Even more so, that the che - yon concept (mchod - yon) which referred to it, ${ }^{17}$ accounting for the relations between the religious preceptor and the donor accorded an at least equal position to the spiritual hierarchy in this arrangement. ${ }^{18}$

Another political reason which could have induced Qianlong to invite the Panchen Lama to China was the desire to sow discord between the political centres in Lhasa (lha sa) and Shigatse ( $g z h i s ~ k a r t s e) .{ }^{19}$ If this was the case, then such a policy would have been a logical continuation of the previously discussed strategy which was put into force in reference to Tibet by Qianlong's predecessors - Kangxi and Yongzheng. Yet another motivation for the presence of the Tashi-Lama in China could be associated with the Emperor's far reaching plan, which stipulated the weakening of the position of the Tibetan aristocracy, and the granting of greater authority to religious hierarchs. ${ }^{20}$ It was none other than Qianlong himself, who accorded to the 7th Dalai Lama the right to exercise both secular and religious authority after the events, which were shocking for the Manchu people, and was associated with the retaliatory killing of Chinese Ambans in 1750. It was at that time that the Emperor, upon hearing the news about the rebellion, was right to introduce direct rule of the Manchu administration in Lhasa, actually divesting the area of Central Tibet of autonomy. It is assumed that it was only the violent, emotional reaction of Changkya Rölpé Dorjé, who was supposed to beseech Qianlong to change this decision, that made the situation in Tibet take a different turn. ${ }^{21}$

The question about the extent to which Qianlong manifested actual respect toward the institution of the Panchen Lamas, and other high-ranking hierarchs of Tibetan Buddhism, including the Dalai Lamas, is open to debate.

${ }^{16} \mathrm{~N}$. Tsyrempilov, Dge lugs pa divided: some aspects of the political role of Tibetan Buddhism in the expansion of the Qing dynasty, p. 49.

${ }^{17}$ D. S. Ruegg, Mchod yon, yon mchod and mchod gnas/yon gnas: On the Historiography and Semantics of a Tibetan Religio-Social and Religio-Political Concept.

${ }^{18}$ D. S. Ruegg, The Preceptor - Donor (yon - mchod) Relation in the Thirteenth Century Tibetan Society and Polity its Inner Asian Precursors and Indian Models, pp. 857-872.

${ }^{19}$ J. Bayer, W. J., Dziak, Tybet, p. 241.

${ }^{20}$ H. Ya, op. cit., p. 141.

${ }^{21}$ S. van Schaik, op. cit., p. 152. 
The answer to this question is associated with another possible reason for inviting the 6th Panchen Lama to China. In contradistinction to the previously discussed exploitative treatment of the invitation, which was issued in order to gain support among the Mongol people, in this case, one should consider whether a crucial reason was also associated with the mere desire to meet a great practising teacher of Tibetan Buddhism. In other words, one should consider whether Qianlong was a practising Tibetan Buddhist, and whether his political decisions should be examined from this perspective. In such a case, the marriage of politics with religion was indissoluble, and it is difficult to discern the place where both spheres should be treated separately. As we mentioned earlier, after all, Qianlong had a personal guru, Changkya Rölpé Dorjé, from whom he received Buddhist instruction and initiation ${ }^{22}$.

Even though Changkya Rölpé Dorjé was considered a reincarnation, his status in the hierarchy of Tibetan Buddhism was lower than the position occupied by the Panchen Lama, though in spite of this, he was still the most important gelug hierarch at the Manchu court. An external manifestation of this hierarchy was e.g. the appointment of places during the receptions held by the emperor where the Panchen Lama could occupy a place which was on equal footing in reference to that of the Emperor, whereas Rölpé Dorjé had to make do with a less prominent place..$^{23}$

Convincing information about the religious nature of Panchen Lama's sojourn in China is also furnished by the accounts devoted to his sojourn in Jehol, and subsequently the ones devoted to his two-month visit to Peking. At that time, the Panchen Lama conducted a number of rituals and initiations especially for the Emperor: a $p \bar{u} j \bar{a}$ to secure the welfare of the country and the long life of the emperor ${ }^{24}$, as well as the Buddhist initiation ceremonies, Mahakala (mgon po), and Cakrasamvara ('khor lo bde mchog). ${ }^{25}$ The Panchen Lama was also introduced to the imperial family, including to Qianlong's six-year-old daughter, to whom he gave a Buddhist name. ${ }^{26}$ During the frequent symposia which were held by the Emperor, which gave an opportunity to conduct conversations between both officials, one discussed politics and religion. One could venture a remark that Jehol was the place of meeting

${ }^{22}$ J. Hevia, Lamas, Emperors and Rituals: Political Implications in Qing Imperial Ceremonies, p. 255 .

${ }^{23}$ W. Xiangyun, op. cit., p. 155.

${ }^{24}$ E. Benard, op. cit., pp. 126-127.

${ }^{25}$ E. Rawski, The Last Emperors. A Social History of Qing Imperial Institutions, p. 258.

${ }^{26}$ N. D. Ragnubs, op. cit., p. 193. 
of two brilliant figures of their times, the patrons of religion and culture, intellects which were open to the world and which were curious about its various forms. The Qianlong Emperor left a great legacy of cultural artifacts, which constitutes the cultural patrimonium of China, and which enhances the tradition of Tibetan Buddhism. ${ }^{27}$ Such an evaluation of the Manchu ruler is legitimate, even if one considers the atrocities which were perpetrated during his reign against the rebellious Tibetans. ${ }^{28}$ It is also worthwhile to remember that Qianlong, who was preparing himself to meet the Panchen Lama, studied the Tibetan language, owing to which he was capable of conducting a simple conversation with his guest in the native language of the latter. ${ }^{29}$ In conclusion, it would be a gross simplification to say that that the birthday excursion in Jehol, which was arranged by the Manchu court, was supposed to serve exclusively political purposes. It is not a point of debate that it was supposed to serve such purposes, but when one evaluates the meeting between Qianlong and Palden Yeshe, one should also take into consideration the question of the individual requirements which this meeting was supposed to satisfy.

Qianlong treated the Panchen Lama with utmost respect during the whole sojourn, taking care of his frame of mind right from his departure from Tashi Lhunpo, as well as during the journey to China which took many months. The Panchen Lama was the addressee of the Emperor's letters, in which the latter expresses his concern about the former's health and the course of the journey..$^{30}$ The entourage which covered the area of Amdo ( $a$ mdo) on its way to the Kumbum monastery ( $s k u$ ' bum), where the Panchen Lama stopped by to spend the winter months, was provided with the means necessary to continue the journey at Qianlong's behest. When the Emperor learnt about the Panchen Lama's decision to undertake the journey to Jehol, he ordered preparation to be engaged on the route followed by his entourage, even though the excessive zeal of some of the local officials was criticised by the court in Peking. ${ }^{31}$ However, the Emperor, who was concerned about how the Panchen Lama endured the toil of travel, even sent him his own sable and leopard furs, which were supposed to protect the latter against the

\footnotetext{
${ }^{27}$ J. Bayer, W. J., Dziak, op. cit., p. 242.

${ }^{28} \mathrm{~K}$. Dhondup, The Water Horse and Other Years, p. 104.

${ }^{29}$ S. Cammann, The Panchen Lama's Visit to China in 1780: An Episode in Anglo-Tibetan Relations, p. 6.

${ }^{30}$ S. van Schaik, op. cit., p. 152.

${ }^{31}$ H. Ya, op. cit., p. 143.
} 
cold. ${ }^{32}$ However, it is worth mentioning the preparations themselves, which were personally supervised by the Emperor and which were undertaken in order to receive the Tibetan lama. ${ }^{33}$ In Jehol, the Emperor built a replica of his home, the Tashi Lhunpo monastery - Xumifushou. After all, it is one of many sacred buildings of this type which were built on the grounds of the summer imperial residence, which were modelled after the existing structures in Tibet. ${ }^{34}$ Testimony to the high estimation in which the Emperor held his guest is furnished by his reaction about the Panchen Lama's ill health, about which he learnt two days before his death. As he decided to visit the sick man, he sent personal doctors to him, at the same time asking them not to inform the Panchen Lama about the unannounced visit, for this might bother the sick man unnecessarily. ${ }^{35}$ Upon learning of the Tashi-Lama's death, Qianlong allegedly fainted for a moment, lapsing into fits of crying and despair. Subsequently, elaborate funeral celebrations were organised at the emperor's behest, and a no less elaborate preparation of a pompa funebris, during which the body of the deceased Panchen Lama was transported to Tibet. ${ }^{36}$ Qianlong is also the author of poems in which he discusses the Panchen Lama's sojourn in China, drawing inspiration from Buddhist symbols. ${ }^{37}$ At the same time, in the context of these events, it is worthwhile to notice that all of the preceding remarks support the rejection of the theory about the purposeful poisoning of the Panchen during his sojourn in Peking. ${ }^{38}$

The motivation which was supposed to guide the Manchu, was associated with the contact with the British which was previously established by the Tashi-Lama, and his permission granted to the mission directed by George Bogle to enter Tibet. This was supposed to be a prelude to the assumption of power in Central Asia by the Panchen Lama with the aid of the British. ${ }^{39}$ The basic counterargument put forward in reference to such conjectures would be associated with the assessment of political losses and gains, disadvantageous for Peking, which would result from such an assassination attempt. ${ }^{4^{\circ}}$

\footnotetext{
${ }^{32}$ M. M. Shu-yi Loo., op. cit., pp. 100-101.

33 P. Berger, Empire of Emptiness: Buddhist Art and Political Authority in Qing China, p. 179.

${ }^{34}$ P. Forêt, Mapping Chengde: the Qing landscape enterprise, p. 51.

${ }^{35}$ M. M. Shu-yi Loo., op. cit., p. 140.

${ }^{36}$ W. Xiangyun, op. cit. pp. $157-158$.

${ }^{37}$ P. Berger, op. cit., p. 193.

$3^{8}$ S. Cammann, op. cit., pp. 15-18.

${ }^{39}$ E. Ludwig, op. cit. p. 18.

${ }^{40}$ S. Cammann, op. cit., pp. 15-18.
} 
However, in considerations of this kind, which refer to conspiracy theories, the "human factor" i.e. the personal likes and dislikes or the more or less concealed admiration manifested toward the partner in a political game is frequently omitted, reducing the decisions made by the leaders merely to a cold calculation of losses and gains.

\section{The reasons which motivated the 6th Panchen Lama's to accept the invitation}

Why did Palden Yeshe accept the invitation from the Emperor then? Obviously, one would be hard put to find a direct answer to this question in historical materials and no answer will be anything more than a mere approximation of the actual motivation which could guide the figures who are discussed. In this case, it is unarguable that one cannot consider Panchen Lama's journey only in one abstracted context - religious, political or any other context, which refers in some way to the events which are discussed. However, in this case, the relationship between politics and religion is all too manifest not to make one associate the facts related with the visit of the Tashi-Lama to China into a consistent image, for both areas constitute an equivalent background to each other for the historical situation which is presented.

It is difficult to state whether Palden Yeshe felt an internal urge to visit the Manchu ruler. The multiple instances of rejection of imperial invitations seem to contradict such a thesis, and perhaps it was only the influence of Changkya Rölpé Dorjé that determined the decision about making the journey. ${ }^{41}$ Panchen's biography strikes the reader with certain idealistic inclinations, which could have influenced his decision. An appropriate example is furnished by the situation associated with the invitation which was issued by the Tashi-Lama to Rölpé Dorjé, so that the latter visited Tashi Lhunpo and provided instruction to him, despite the fact that, as it was stated before, he occupied a position in the hierarchy of the Buddhist tulkus that was inferior to that of the Panchen Lama. However, the opposition on the part of the closest associates of the Panchen Lama, of the lamas who jealously guarded their own position, rendered this visit impossible..$^{42}$ Also, the ac-

\footnotetext{
${ }^{41}$ P. Berger, op. cit., p. 179.

${ }^{42}$ W. Xiangyun, op. cit., p. 152.
} 
count of the conversations of the visit of Bogle in Tashi Lhunpo is testimony to the broad intellectual interests of the Panchen, of his curiosity about the world, and the fascination generated by various cultures. ${ }^{43}$ However, all of these remarks are not sufficient to make one state that the desire itself to meet the Emperor and to see China was the main motivation to undertake the journey, although, on the other hand, it enables us to state that it was one of the factors which motivated that journey.

The Panchen Lama accepted the invitation of Qianlong, perhaps because he reckoned that there was nothing else he could do. After the events associated with the abortive attempt to make Tibet independent from the Manchu, which was made by Gjurme Namgjal (gyur med rnam rgyal), the Manchu influence upon the politics in Lhasa became more pronounced than at the time of the skillful rule of Pholhane (pho lha nas). In 1751, by issuing an edict which regulated the functioning of Tibetan administration, the Manchu directly affected the very structure of the functioning of authority in Central Tibet. ${ }^{44}$ For when Kangxi, a few decades earlier, approved the dethroning of Tsangyang Gyatso (tshangs dbyangs rgya mtsho) and enthroned the new Dalai Lama, Yeshe Gjatso (ye shes rgya mtsho), the issue was associated with the replacement of the person who represented the same institution. However, the reorganisation of the Kashag ( $b k a$ ' shag), the abolition of monarchic titles and the granting of secular authority to the Dalai Lama and the Ambans, indicate a much deeper political interference on the part of Peking. The Panchen Lama could therefore be forced to meet Qianlong, who, as it is indicated by the facts, at that time determined to a great extent the nature of politics and religion in Tibet.

During Qianlong's reign, the Manchu state entered a period of culmination of its splendour, and managed to support its political aspirations with military power, about which Tibet learnt at least twice at that time, due to the previously mentioned events of 1750 and during the wars with the Nepal Gurkhas of 1788 and 1792. Another instance of the rejection of the prospect of coming to China on the part of the Panchen Lama, and that in relation to such a prestigious meeting i.e. the celebration of the emperor's birthday, could weaken Tashi Lhunpo's position in the political arena of Tibet. The Tashi-Lama felt awe and ostentatious veneration in reference to the Emperor,

\footnotetext{
${ }^{43}$ G. T. Stewart, 1774: The Scottish Enlightenment Meets the Tibetan Enlightenment, p. 477. ${ }^{44}$ J. Bayer, W. J. Dziak., op. cit. p. 237.
} 
and to the latter's decrees and letters. ${ }^{45}$ Tibetan and Chinese sources differ in the evaluation of the Panchen Lama's behaviour toward Qianlong during their meeting in Jehol. ${ }^{46}$ However, even if the Panchen Lama did not bow before the Emperor, he did manifest respect toward him - respect which characterises the attitude of a vassal to a monarch, for it was the Emperor who gracefully permitted his guest not to genuflect before his power and majesty. ${ }^{47}$ Moreover, also in the symbolic sphere, the Manchu court imposed a sort of regency to Panchen Lamas by granting them the Mongol title "Erdeni" (er te ni), which corresponds to the Tibetan term "Rinpoche" (rin po che), i.e. "precious". Just as Lobsang Yeshe was the recipient of this title on the part of Emperor Kangxi, Palden Yeshe received it under Qianlong's decree. ${ }^{4}$ All of these elements are testimony that the Panchen Lama, who after the death of 7 th Dalai Lama, as it was already mentioned, was one of the most important figures of Tibet ${ }^{49}$, could face a negative reaction on the part of the Emperor for refusing to participate in the celebration of his birthday. On the other hand, if the Panchen Lama sought this opportunity to strengthen his political position on central Tibet to the detriment of the administration in Lhasa, then a visit during the celebration of the emperor's birthday furnished a splendid opportunity in this respect. The Panchen Lama's opinion about the 8th Dalai Lama's talents and progress in studies was carefully recognised by the Emperor. ${ }^{50}$ During many conversations between Qianlong and his guest, the problems which were directly associated with the political situation in Tibet supposedly recurred; one also made plans in reference to the future state of affairs. Without a doubt, one of the problems was associated with the recognition of the reincarnation of the deceased regent, Demo Tulku. ${ }^{11}$ The fact that the Panchen Lama directly discussed those problems with the Emperor, without doubt placed him in a privileged position in reference to his political competitors.

The Panchen Lama's journey to China confirmed his status as a spiritual leader among the Mongol people. In this case, the propaganda-related be-

\footnotetext{
45 H. Ya., op. cit., p. 135.

${ }^{46}$ Ibidem., p. 241. [See] also: W. W. Smith Jr, Tibetan nation: a history of Tibetan nationalism and Sino-Tibetan relations, p. 133.

${ }^{47}$ W. Xiangyun, op. cit., p. 154.

${ }^{4}$ H. Ya, op. cit., p. 135.

${ }^{49}$ M. T. Kapstein, op. cit., p. 165.

$5^{\circ}$ N. D. Ragnubs, op. cit., p. 196.

${ }^{51}$ M. M. Shu-yi Loo., op. cit., pp. 175-176.
} 
nefits resulting from the meeting in Jehol and from a further visit could be gained by both him and the Emperor. The Mongol princes who represented the particular areas of Mongolia conquered by the Manchu people, who came to the imperial residence in order to participate in the celebration of the birthday of the host, could observe the lavish reception ceremony of the lama and the honours rendered to him by the Manchu people, as well as the Emperor himself and his family. Such a show surely must have made an impression on them, and legitimised the spiritual and the political power wielded by the Tashi-Lama. Also, the journey to Jehol, which lasted more than a year, mentioned in the short biography ${ }^{52}$, may be perceived as a perfect opportunity to promote the image of the Panchen Lamas as the spiritual regents of the Mongol people. The accounts of the journey mention the throngs of the faithful who gathered to see the Panchen Lama on the route of his itinerary, and who desired to receive a blessings from the venerable man. In the Kokonor region, the crowds of the Tibetan and the Mongol people who expected to see the Panchen Lama was so great, that the human throngs forked into two rows, lining up in a queue to receive a blessings. Only a part of those who thronged from dawn till dusk could receive a blessings from the Tashi-Lama. When so many people pressed forward, there was a threat that the throne on which the Panchen Lama was seated would be overturned, so the Palden Yeshe who attempted to bring the situation under control rose and threw handfuls of barley in a gesture of blessing to the people who were gathered there. ${ }^{53}$

Testimony to the influence of the visit that was exerted on the Mongol subjects of Qianlong is also furnished by an inscription on a stupa, which commemorates the sojourn and the death of the 6th Panchen Lama, erected by the Emperor on the grounds of the Yellow Temple. ${ }^{54}$ The Panchen Lama, as one of the supreme reincarnations of the gelug, exerted a pervasive influence upon the intellectual and religious ambience in Mongolia. His extraordinary pilgrimage to China, part of which included the lands of Inner Mongolia, contributed to the strengthening of the image of his financial power and spiritual greatness.

The Panchen Lama's visit and his meeting with Qianlong could also serve a very specific purpose. After Bogle's stay, the emissary of Warren Hastings

${ }^{52} \mathrm{pN}$ chen dpal ldan ye shes kyi gsung 'bum gyi dkar chag dang rnam thar mdor bsdus, p. 114 .

${ }^{53}$ M. M. Shu-yi Loo, op. cit. p. 94 .

${ }^{54}$ E. Ludwig, op. cit., p. 30. 
in Tashi Lhunpo at the turn of $1775^{55}$, the British not only established a contact with the Tashi-Lama, but, as it seems, they also won his support. The Panchen Lama promised to intercede for Bogle at the imperial court in reference to the visit of the British diplomatic delegation in Peking. The goal of the British at that time was to establish trade relations with Tibet, which was supposed to be the first step toward the opening of the Chinese market for the East India Company. It is possible to assume, with a great degree of probability, that in this way, the Panchen Lama intended to do a favour to the advena from Europe, whom he supposedly liked ${ }^{56}$, and aslo, to drew benefit from the opportunities offered by lucrative trade. However, in order to service this ambition, one required the consent of the Manchu and a consistent policy in this regard. According to some sources, the Panchen Lama received imperial assurance in terms of the possibility of establishing diplomatic relations with the Company. The Emperor even supposedly gave him the possibility of choosing the manner of the providing of the letter written by Qianlong to Hastings, ${ }^{57}$ even though sources differ as far as the probability of such a situation..$^{8}$

\section{Conclusion}

The article presents a number of reasons which could have influenced the organisation and the course of the meeting of the 6th Panchen Lama with Emperor Qianlong. We may enumerate them in the following manner:

Why did Qianlong invite the Panchen Lama to China? In this way he intended:

- to confirm the position, which he ascribed to himself - the superior figure of Tibet;

- to impress the Mongol political and religious elites;

- to meet a great teacher of Tibetan Buddhism whom he sincerely respected;

- the continue the Qing policy of sowing discord between the centres of authority in Central Tibet, Shigatse and Lhasa;

${ }^{55}$ C. R. Markham, Narratives of the Mission of George Bogle to Tibet and the fourney of Thomas Manning to Lhasa.

${ }^{56}$ P. Berger, op. cit., p. 168.

${ }^{57}$ S. Cammann, op. cit., p. 12.

${ }^{5}$ Ibidem, p. 15. 
- to strengthen the position of the gelug in China, which he considered an important element of the internal policy of the empire, whose purpose was to subordinate the peoples who adhered to Tibetan Buddhism.

Why did the Panchen Lama accept the Emperor's invitation?

- in fear of an unfavourable reaction on the part of the emperor and the risk of losing his political position in Tibet;

- in order to confirm his charisma among the Mongol people;

- in order to receive imperial consent to conduct trade with the East India Company;

- in order to enhance Tashi Lhunpo's position in reference to Lhasa;

- as a remarkable individual, he was interested in the world, was open to meeting the Manchu ruler, and intended to expand his religious knowledge by meeting Changkya Rölpé Dorjé.

The suggestions listed above are based on the theses which were previously put forward by other authors. However, this does not at all mean that this "high-level" 18th-century meeting was not associated with other reasons, as, for example, the establishment of a personal che-yon relation between the 6th Panchen Lama and the Qianlong Emperor. An analysis of this aspect of Palden Yeshe's visit in Chengde is interesting in the context of the topic under discussion. However, only further research, including research in Tibetan and Chinese source texts, may provide more reliable data in this respect. 


\section{Bibliography}

1. BaAbar, Dzieje Mongolii, S. Godziński (trans.), Wydawnictwo Akademickie Dialog, Warszawa 2009.

2. Bayer J., Dziak W. J., Tybet, Instytut Studiów Politycznych Polskiej Akademii Nauk, Warszawa 2015.

3. Benard E., The Qianlong Emperor and Tibetan Buddhism, [in:] J. A. Millward et al. (ed.), The New Qing Imperial History, Routledge, London \& New York 2004, pp. 123-135.

4. Berger P., Empire of Emptiness: Buddhist Art and Political Authority in Qing China, University of Hawai'i Press, Honolulu 2003.

5. Cammann S., The Panchen Lama's Visit to China in 1780: An Episode in Anglo-Tibetan Relations, "The Far Eastern Quarterly" 9 (1/1949), pp. $3^{-19}$.

6. Dhondup K., The Water Horse and Other Years, LTWA, Dharamsala 1984.

7. FARQuhar D. M., Emperor as Bodhisattva in The Governance of The Ch'ing Empire, "Harvard Journal of Asiatic Studies" 38 (1/1978), pp. $5^{-34}$.

8. FonÊT P., Mapping Chengde: the Qing landscape enterprise, Honolulu, University of Hawai'i Press, Honolulu 2000.

9. Grupper S. M., Manchu Patronage and Tibetan Buddhism During the First Half of the Ch'ing Dynasty, "The Journal of the Tibetan Society" 4/1984, pp. 47-75.

10. Hevia J., Lamas, Emperors and Rituals: Political Implications in Qing Imperial Ceremonies, "Journal of the International Association of Buddhist Studies" 6 (2/1993), pp. 243-278.

11. Kapstein M. T., Tybetańczycy, J. Hunia (trans.), Wydawnictwo Uniwersytetu Jagiellońskiego, Kraków 2010.

12. Ludwig E., The Visit of the Teshoo Lama to Peking, Tientsin Press, Peking 1904 .

13. Markham C. R., Narratives of the Mission of George Bogle to Tibet and the fourney of Thomas Manning to Lhasa, Trübner and Co., London 1879.

14. $p N$ chen dpal ldan ye shes kyi gsung 'bum gyi dkar chag dang rnam thar mdor bsdus, [in:] po ta lar bzhugs pa'i dge lugs gsung 'bum gyi dkar chag Volume 1, bod ljongs mi dmangs dpe skrun khang, lha sa 1990. 
15. Ragnubs N. D. (trans.), The Third Panchen Lama's visit to Chengde, [in:] J. A. Millward et al. (ed.), The New Qing Imperial History, Routledge, London \& New York 2004, pp. 188-198.

16. Rawski E., The Last Emperors. A Social History of Qing Imperial Institutions, University of California Press, Berkeley 1998.

17. Ruegg D. S., Mchod yon, yon mchod and mchod gnas/yon gnas: On the Historiography and Semantics of a Tibetan Religio-Social and ReligioPolitical Concept, [in:] E. Steinkellner (ed.), Tibetan History and Language: Studies Dedicated to Uray Geza on his Seventieth Birthday, Arbeitskreis für Tibetische und Buddhistische Studien, Universität Wien, Wien 1991, pp. 441-454.

18. Ruegg D. S., The Preceptor-Donor (yon-mchod) Relation in the Thirteenth Century Tibetan Society and Polity its Inner Asian Precursors and Indian Models, [in:] H. Krasse et al. (ed.), Proceedings of the 7th Seminar of the International Association for the Tibetan Studies, Verlag der Österreichischen Akademie der Wissenschaften, Graz 1995, pp. 857-872.

19. VAn Schaik S., Tibet, Yale University Press, New Haven \& London 2011.

20. Shu-yi Loo M. M., The Biography of the III Panchen Lama Blo-bzangdpal-Ldan-yes-she-dpal-bzang-po, Examined in the Light of Sino-Tibetan Relations during the late Eighteen Century, $\mathrm{PhD}$ thesis, University of Washington, 1970.

21. Sмiтн Jr W. W., Tibetan nation: A History of Tibetan Nationalism and Sino-Tibetan Relations, Westview Press, Colorado \& Oxford 1996.

22. Stewart G. T., 1774: The Scottish Enlightenment Meets the Tibetan Enlightenment, "Journal of World's History" 22 (3/2011), pp. 455-492.

23. Tsyrempilov N., Dge lugs pa divided: some aspects of the political role of Tibetan Buddhism in the expansion of the Qing dynasty, [in:] B. J. Cuevas, K. R. Schaeffer (eds.), Power, Politics and the Reinvention of the Tradition, PIATS 2003: Tibetan Studies: Proceedings of the Tenth Seminar of the International Association for Tibetan Studies, Brill, Leiden \& Boston 2006, pp. 47-64.

24. Xiangyun W., The Qing Court's Tibet Connection: Lcang skya Rol pa'i rdo rje and the Qianlong Emperor, "Harvard Journal of Asiatic Studies" $60(1 / 2000)$, pp. 125-163.

25. YA H., Biographies of the Tibetan Spiritual Leaders, Foreign Languages Press, Beijing 1994. 